\title{
4- Dil öğretiminde YouTube’un kullanımı: Yabancılara Türkçe öğretenlerin deneyimleri ve bakış açıları ${ }^{1}$
}

\section{Önder ÇANGAL ${ }^{2}$}

APA: Çangal, Ö. (2021). Dil öğretiminde YouTube’un kullanımı: Yabancılara Türkçe öğretenlerin deneyimleri ve bakış açları. RumeliDE Dil ve Edebiyat Araştırmaları Dergisi, (Ö10), 63-80. DOI: 10.29000/rumelide.1009040.

\section{$\ddot{O} \mathbf{z}$}

Teknolojik gelişmelerle akıllı telefonların hayatımızdaki öneminin artması ve internete erişimin kolaylaşması bilgiye ulaşma ve bilgiyi tüketme yollarında birtakım değişikliklerin yaşanmasına neden olmuştur. İnsanlar bugün bilgiye ulaşmak için internete başvurmakta, bu sayede akıllarına takılan sorulara cevaplar bulmaktadır. İnternetteki bilgiler her zaman doğru olmamakla birlikte tüketilebilir bilginin insanlara ulaştırılması aşamasında hazırlanan internet platformları önemli birer araç olarak dikkat çekmekte, bu aşamada YouTube platformu popüler bir uygulama olarak ön plana çıkmaktadır. İnsanlar müzik dinlemek, ürün incelemek, haberleri takip etmek, film izlemek ve hatta dil öğrenmek için YouTube'u kullanmaktadır. Yapılan çalışmalar da sosyal medya araçlarının planlı ve amaçlı şekilde kullanıldıklarında dil öğretimine katkısı olduğunu ortaya koymaktadır. Bu nedenle bu çalışmada dil öğretiminde YouTube’un kullanımı konusu ele alınmış, yabancılara Türkçe öğretenlerin öğretim süreçlerinde YouTube'dan yararlanma ile ilgili görüşlerine başvurulmuştur. Nitel araştırma yöntemi kullanılarak hazırlanan çalışma, yabancılara Türkçe öğretiminde YouTube kullanımına yönelik öğretici görüşlerini ortaya koyan bir durum çalışmasıdır. Araştırmada veri toplamak için görüşme formları kullanılmıştır. Görüşme formlarından elde edilen veriler içerik analizi kullanılarak incelenmiş, elde edilen sonuçlardan hareketle yabancılara Türkçe öğretiminde YouTube kullanımına yönelik değerlendirmeler yapılmıştır.

Anahtar kelimeler: Yabancılara Türkçe öğretimi, teknoloji destekli öğretim, sosyal medya, YouTube

\section{The use of YouTube in language teaching: Experiences and perspectives of those teaching Turkish to foreigners}

\begin{abstract}
The increase in the importance of smart phones in our lives with technological developments and the ease of access to the internet have led to some changes in the ways of accessing and consuming information. Nowadays, people resort to the internet to access information, and by this way, they find out suitable answers to their questions. Even though the information on the Internet is not always reliable, the Internet platforms prepared during the phase of delivering consumable information to people regarded as an important tool, and at this point, the YouTube platform stands out as a popular application. People utilize from YouTube to listen to music, review products, follow the news, watch movies and even learn languages. Studies also reveal that social media tools contribute to language
\end{abstract}

Gaziantep Üniversitesi, Sosyal ve Beşeri Bilimler Etĭgi Kurulunun E-39083294-050.06-39367 sayll yazısı ile araştırma için gerekli olan etik kurul izni alınmıştır.

Dr., Gaziantep Üniversitesi, Türkçe Öğretimi Uygulama ve Araştırma Merkezi (Gaziantep, Türkiye), ondercangal@hotmail.com, ORCID ID: 0ooo-0002-8560-3526 [Araştırma makalesi, Makale kaylt tarihi: 26.09.2021kabul tarihi: 20.10.2021; DOI: 10.29000/rumelide.1009040]

Adres | Address

RumeliDE Dil ve Edebiyat Araşturmaları Dergisi $\quad$ RumeliDE Journal of Language and Literature Studies Osmanağa Mahallesi, Mürver Çiçeği Sokak, No:14/8 $\quad$ Osmanağa Mahallesi, Mürver Çiçeği Sokak, No:14/8

Kadıköy - İSTANBUL / TÜRKIYE 34714 Kadıköy - ISTANBUL / TURKEY 34714 e-posta: editor@rumelide.com e-mail: editor@rumelide.com, tel: +90 505 7958124, +90 2167730616 phone: +90 505 7958124, +90 2167730616 
The use of YouTube in language teaching: Experiences and perspectives of those teaching Turkish to foreigners / Ö. Çangal (pp. 63-80)

teaching when they are used in a planned and purposeful way. For this reason, in this study, the use of YouTube in language teaching has been discussed, and the views of teachers about using YouTube in teaching Turkish to foreigners have been consulted. The study, which was prepared using the qualitative research method, is a case study that reveals the views of teachers on the use of YouTube in teaching Turkish to foreigners. Interview forms were used to collect data in this study. The data obtained from the interview forms were analyzed by using content analysis, and according to the results based on obtained data, evaluations were made regarding the use of YouTube in teaching Turkish to foreigners.

Keywords: Teaching Turkish to foreigners, technology-assisted teaching, social media, YouTube

\section{Giriş}

Teknolojik gelişmelerle akıllı telefonların hayatımızdaki öneminin artması, internete erişimin kolaylaşması bilgiye ulaşma ve bilgiyi tüketme yollarında birtakım değişikliklerin yaşanmasına neden olmuştur. İnsanlar bugün tüm iş ve işlemlerini internet araçları üzerinden gerçekleştirmekte, pandemi nedeniyle yüz yüze eğitim ortamları uzaktan eğitim sistemlerine aktarılmakta, bu durum kendi kendine öğrenmenin önem kazanmasına neden olmaktadır.

Bireysel öğrenme; öğretici denetiminden, zamandan ve mekândan bağımsız olarak öğrenici inisiyatifinde gerçekleşir. Bu aşamada ilgi çekici, birden fazla duyu organına hitap eden eğlenceli videolar hazırlamak ve uygulamalar geliştirmek çok önemlidir. Bu sayede kişilerin öğrenme hedeflerine uygun bir şekilde hazırlanan içerikleri takip etmesi ve verilmesi hedeflenen kazanımlara ulaşması mümkün hâle gelecektir.

Öğrenme amacı olmaksızın farklı gerekçelerle interneti kullanan kişiler, zaman zaman istenmeyen öğrenmelere maruz kalmaktadır. Çocukların izledikleri video ve çizgi filmlerden hareketle yabancı dil öğrenmesi buna örnek olarak gösterilebilir. Burada çocuklar herhangi bir öğrenme amacı olmaksızın videoları izlemekte, izledikleri videolar sayesinde ana dili edinimine benzer bir şekilde yabancı dil öğrenmektedir.

Gerek bireysel öğrenme amacıyla gerekse internet araçları üzerinde farklı gerekçelerle vakit geçirme nedeniyle insanlar, bilgi dünyalarını geliştirme fırsatı bulmaktadır. İnternetteki bilgiler her zaman doğru olmamakla birlikte tüketilebilir bilginin insanlara ulaştırılması aşamasında hazırlanan internet platformları önemli birer araç olarak dikkat çekmekte, bu aşamada YouTube platformu popüler bir uygulama olarak ön plana çlkmaktadır.

İnsanlar farklı gerekçelerle YouTube'daki videoları izlemekte, hatta dil öğrenmek için YouTube'u kullanmaktadır. Yapılan çalışmalar (bk. Ayu, 2016; Çangal, 2020; Meinawati vd., 2020) da YouTube'un planlı ve amaçlı şekilde kullanıldığında dil öğretim süreçlerine katkısı olduğunu ortaya koymaktadır. Bu nedenle bu çalışmada dil öğretiminde YouTube'un kullanımı konusu ele alınmış, yabancılara Türkçe öğretenlerin öğretim süreçlerinde YouTube'dan yararlanma ile ilgili görüşlerine başvurulmuştur.

\section{Araştırmanın amacı}

Araştırmada dil öğretiminde YouTube kullanımına yönelik tespitlerde bulunmak, yabancılara Türkçe öğretenlerin derslerde YouTube kullanımına yönelik deneyim ve bakış açılarını ortaya koymak amaçlanmıştır.

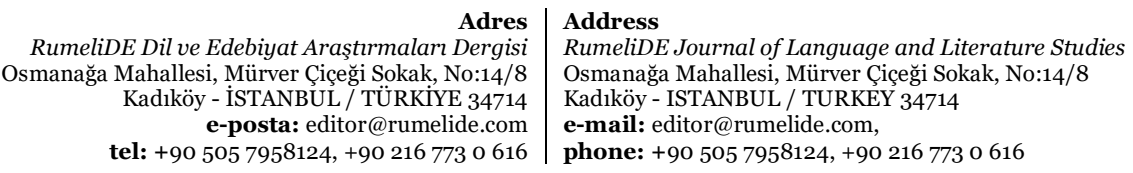


$\mathrm{Bu}$ amaç doğrultusunda araştırmada aşağıdaki sorulara cevap aranmıştır:

1. Öğreticilerin yabancılara Türkçe öğretimi süreçlerinde YouTube'dan yararlanılması hakkındaki düşünceleri nelerdir?

2. Yabancılara Türkçe öğretenlerin derslerinde YouTube’u kullanma alışkanlıkları nasıldır?

3. Yabancılara Türkçe öğretiminde YouTube kullanımının olumlu ve olumsuz yönleri nelerdir?

\section{Yöntem}

Nitel araştırma yöntemi kullanılarak hazırlanan çalışma, yabancılara Türkçe öğretiminde YouTube kullanımına yönelik öğretici görüşlerini ortaya koyan bir durum çalışmasıdır. Durum çalışması "Nasıl ve niçin sorularını temel alan, araştırmacının kontrol edemediği bir olgu ya da olayı derinliğine incelemesine olanak veren araştırma yöntemidir" (Yıldırım ve Şimşek, 2018, s. 289).

Araştırma kapsamında yabancı ve ikinci dil olarak Türkçe öğreten öğreticilerden veri toplandığı için 18.03.2021 tarihinde 27072 sayılı yazı ile "Gaziantep Üniversitesi Sosyal ve Beşeri Bilimler Etik Kurulu”na başvurulmuş, araştırma kurul tarafindan incelenerek 27.04.2021 tarihinde 7 numaralı toplantıda alınan 53 numaralı karar ile etik açıdan uygun bulunmuştur.

\section{Çalışma grubu}

Araştırmanın çalışma grubunu Türkiye'de ve yurt dışında Türkçeyi yabancı ve ikinci dil olarak öğreten 50 öğretici oluşturmaktadır. Katılımcılara ait kişisel veriler şu şekildedir:

Tablo 1. Katılımclların Demografik Verileri

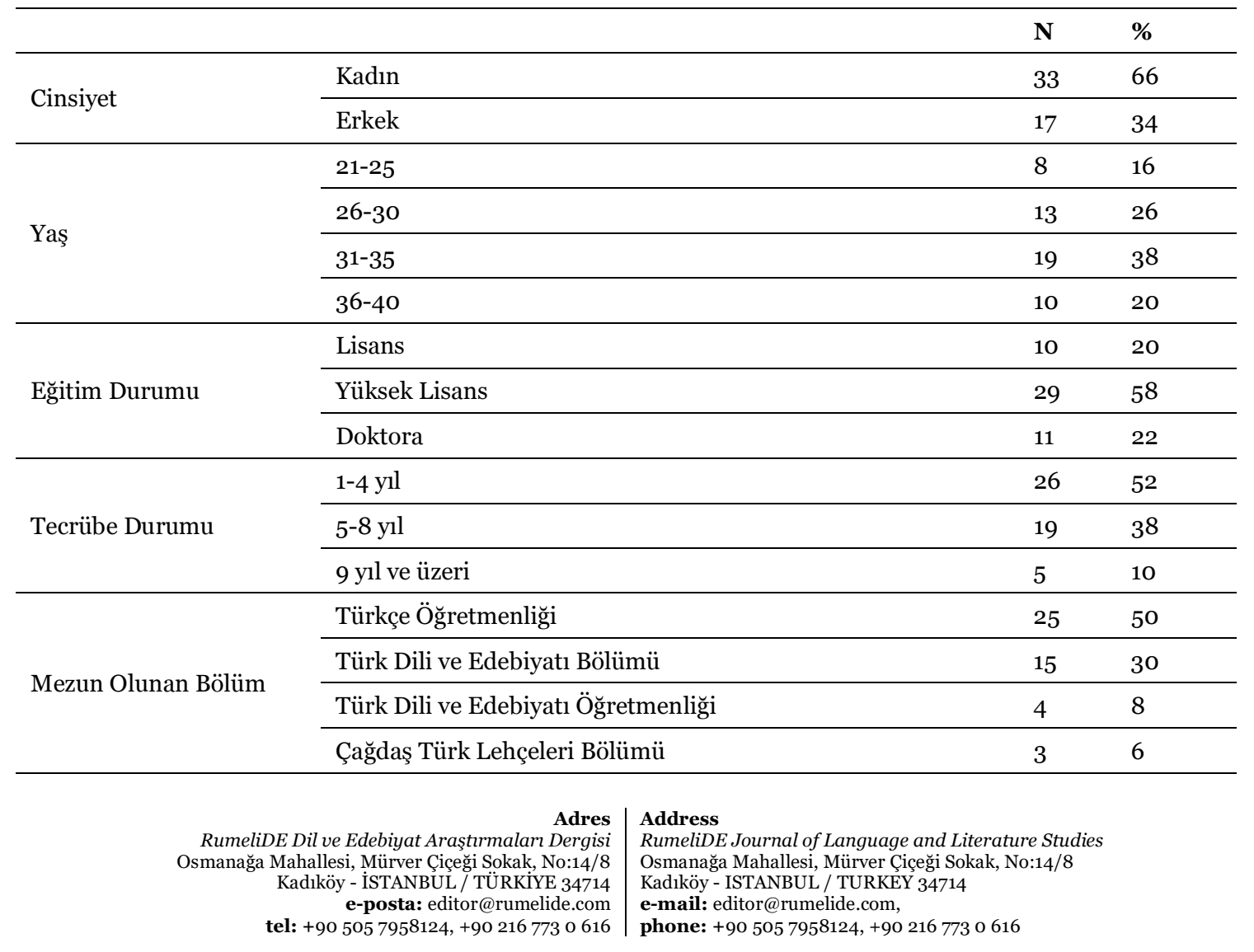




\begin{tabular}{llll}
\hline & İngilizce Öğretmenliği & 1 & 2 \\
\cline { 2 - 4 } & Fransızca Öğretmenliği & 1 & 2 \\
\cline { 2 - 4 } & Mütercim Tercümanlık Bölümü & 1 & 2 \\
\hline \multirow{2}{*}{ YTÖ Sertifika Durumu } & Evet & 38 & 76 \\
\cline { 2 - 4 } & Hayır & 12 & 24 \\
\hline \multirow{3}{*}{ Görev Yapılan Kurum } & İstanbul Sabahattin Zaim Üniversitesi & 15 & 30 \\
\cline { 2 - 4 } & Yunus Emre Enstitüsü & 15 & 30 \\
\cline { 2 - 4 } & Ankara Yıldırım Beyazıt Üniversitesi DİLMER & 5 & 10 \\
\cline { 2 - 4 } & Gazi Üniversitesi TÖMER & 5 & 10 \\
\cline { 2 - 4 } & Gaziantep Üniversitesi TÖMER & 5 & 10 \\
\cline { 2 - 4 } & İstanbul Aydın Üniversitesi TÖMER & 5 & 10 \\
\hline
\end{tabular}

Katılımcıların otuz üçü (\%66) kadın, on yedisi (\%34) ise erkektir. Araştırmaya katılan öğreticiler 21-40 yaş aralığındadır. Öğreticilerin yüzde 16'sı 21-25 yaş, yüzde 26'sı 26-30 yaş, yüzde 38'i 31-35 yaş ve yüzde 20'si 36-40 yaş arasındadır. Öğreticilerin 10'u lisans, 29'u yüksek lisans ve 11'i doktora mezunudur. Öğreticilerin yüzde 52'si 1-4 yll, yüzde 38’i 5-8 yll ve yüzde 10’u 9 yll ve üzeri yabancllara Türkçe öğretimi tecrübesine sahiptir.

Veriler incelendiğinde kadın öğreticilerin erkeklerden daha fazla olduğu, çalışma grubunda üniversitelerin lisans programlarından mezun olur olmaz göreve başlayanların (\%16) da yer aldığı, bununla birlikte özellikle 31-35 yaş arası (\%38) öğreticilerin çoğunlukta olduğu görülmektedir. Öğreticilerin tecrübe durumları da yaşları ile benzer sonuçlar göstermekte, öğreticilerin tecrübeleri 1-8 yıl arasında yoğunlaşmaktadır. 9 yl ve üzeri süredir yabancılara Türkçe öğretenler, katılımcıların yalnızca yüzde 1o'unu oluşturmaktadır.

Katılımcıların mezun oldukları bölümler incelendiğinde öğreticilerin yüzde 50'sinin Türkçe öğretmenliği, yüzde 3o'unun Türk dili ve edebiyatı bölümü, yüzde 8'inin Türk dili ve edebiyatı öğretmenliği ve yüzde 6'sının çağdaş Türk lehçeleri bölümü mezunu olduğu görülmüştür. İngilizce öğretmenliği, Fransızca öğretmenliği ve mütercim tercümanllk bölümlerinden ise 1'er öğretici araştırmaya katılmıştır.

Öğreticilere yabancılara Türkçe öğretimi sertifikalarının olup olmadığı sorulduğunda öğreticilerin yüzde 76'sı sertifikasının olduğunu, yüzde 24'ü ise sertifikasının olmadığını söylemiştir. Araştırmaya altı farklı kurumdan öğretici katılmıştır. Katılımclların yüzde 30’u İstanbul Sabahattin Zaim Üniversitesinde ve yüzde 3o’u Yunus Emre Enstitüsünde görev yapmaktadır. Ankara Yıldırım Beyazıt, Gazi, Gaziantep ve İstanbul Aydın Üniversitelerinden ise 5'e öğretici araştırmaya dâhil edilmiştir.

\section{Veri toplama araçları ve verilerin analizi}

Öğreticilerden görüş toplamak için araştırmacı tarafından hazırlanan yapılandırılmış görüşme formu kullanılmıştır. Form hazırlandıktan sonra Türkiye'de ve Türkiye dışında yabancılara Türkçe öğreten 5 uzmana sunulmuş, uzmanlardan gelen dönütler doğrultusunda görüşme formuna son şekli verilmiştir.

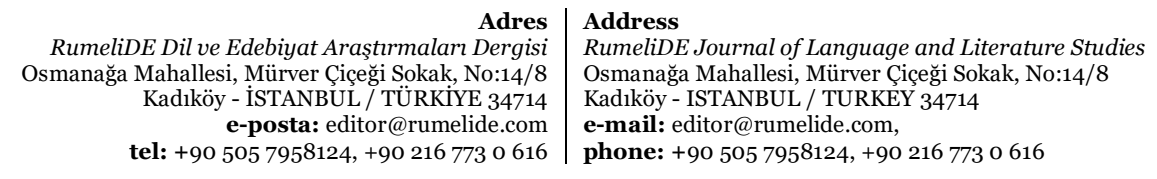


Yapılandırılmış görüşme formu iki bölümden oluşmaktadır. Formun ilk bölümünde katılımcıların kişisel bilgilerini tespit etmeye yönelik sorular bulunmaktadır. Kişisel bilgilerin belirlenmesi amacıyla sorulan sorular şu şekildedir:

- Cinsiyetiniz nedir?

- Kaç yaşındasınız?

- Eğitim durumunuz nedir?

- Kaç yıldır yabancılara Türkçe öğretiyorsunuz?

- Hangi bölümden mezun oldunuz?

- Yabancılara Türkçe öğretimi sertifikanız var mı?

- Hangi kurumda çalışıyorsunuz?

İkinci bölümde katılımcıların yabancılara Türkçe öğretimi süreçlerinde YouTube'u kullanma alışkanlıklarının ve süreçte YouTube kullanımı hakkındaki görüşlerinin belirlenmesine yönelik sorular sorulmuştur. İkinci bölümdeki sorular şunlardır:

- YouTube'un yabancılar için Türkçe öğretimi süreçlerinde kullanılması hakkında ne düşünüyorsunuz?

- YouTube, gelecek yıllarda yabancı dil öğretimi alanını nasıl etkiler? Siz bu konuda neler düşünüyorsunuz?

- YouTube'u ne sıklıkla kullanıyorsunuz?

- YouTube’u en çok hangi teknolojik araçlar üzerinden kullanıyorsunuz?

- Türkçe öğretmek amacıyla YouTube’u kullanıyor musunuz?

- YouTube kullanılarak hangi beceri(ler) geliştirilebilir?

- YouTube, dil becerilerinin (okuma, dinleme, konuşma ve yazma) geliştirilmesinde nasıl kullanılabilir?

- Ders sürecinde en çok hangi durumlarda YouTube videolarından faydalanıyorsunuz?

- Düzenli olarak takip ettiğiniz yabancılara Türkçe öğretimi kanalları varsa isimlerini yazınız.

- Size göre Türkçe öğretirken YouTube kullanılmasının olumlu yönleri nelerdir?

- Size göre Türkçe öğretirken YouTube kullanılmasının olumsuz yönleri nelerdir?

Araştırma kapsamında elde edilen verilerin analizinde içerik analizi kullanılmıştır. "İçerik analizi amaçları belirleme, kavramları tanımlama, analiz birimlerini belirleme, konu ile ilgili verilerin yerlerini belirleme, mantıksal bir yapıyı geliştirme, kodlama kategorilerini belirleme, sayma, yorumlama ve sonuçları yazma aşamalarından oluşmaktadır” (Büyüköztürk vd., 2016, s.251).

\section{Bulgular}

\section{1. Öğreticilerin yabancılara Türkçe öğretimi süreçlerinde YouTube'dan yararlanılması hakkındaki düşünceleri nelerdir?}

Araştırma kapsamında katılımcılara YouTube’un yabancılara Türkçe öğretimi süreçlerinde kullanılması hakkındaki düşünceleri sorulmuş, elde edilen veriler sekiz farklı kod altında toplanmıştır. Öğreticilerin derslerde YouTube'un kullanılması hakkındaki düşüncelerine ilişkin frekans ve yüzdeler şu şekildedir:

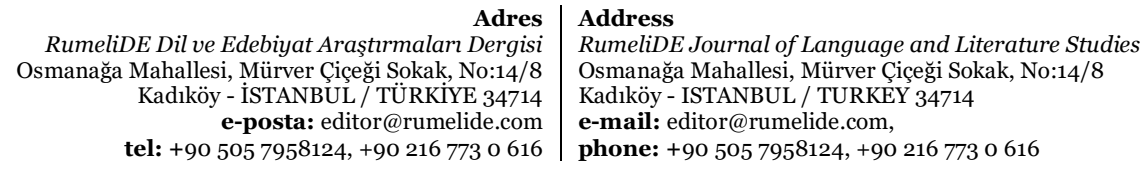


The use of YouTube in language teaching: Experiences and perspectives of those teaching Turkish to foreigners / Ö. Çangal (pp. 63-80)

Tablo 2. Öğreticilerin Derslerde YouTube’un Kullanılması Hakkındaki Düşüncelerine İlişkin Frekans ve Yüzdeler

\begin{tabular}{llll}
\hline Tema & Kodlar & f & \% \\
\hline & Dil becerilerini geliştirme & 12 & 24 \\
& Fayda sağlama & 10 & 20 \\
& Öğrenmeyi destekleme & 9 & 18 \\
YouTube'un yabancılara Türkçe öğretimi & Eğlenerek öğrenme imkânı sunma & 7 & 14 \\
süreçlerinde kullanılması & Öğrenilenleri pekiştirme & 6 & 12 \\
& Bilgiyi somut hâle getirme & 3 & 6 \\
& İnteraktif öğrenme să̆lama & 2 & 4 \\
\hline & Video ile öğrenme sağlama & 1 & 2 \\
\hline
\end{tabular}

Katılımcıların tamamı dil öğretim süreçlerinde YouTube kullanımı ile ilgili görüş bildirmiştir. Katılımcılardan 12'si (\%24) YouTube'un dil becerilerini geliştirdiğini düşünmektedir. Konuyla ilgili olarak K21 YouTube'un dinleme, yazma ve konuşma becerisi ile dil bilgisi yeterliklerinin geliştirilmesi için öğrenciler tarafından tercih edildiğini, K26 hem görüntü hem de sesin birlikte verilmesi nedeniyle YouTube’un öğrenicilerin dinleme ve konuşma becerilerini desteklediğini ve K36 platformun dinleme izleme becerisini geliştirmede başarılı olduğunu ifade etmiştir.

Öğreticilerin 10’u (\%20) YouTube'un öğrenme süreçlerine fayda sağladığını, 9’u (\%18) öğrenmeyi desteklediğini, 7'si (\%14) öğrenicilerin eğlenerek öğrenme imkânı bulduklarını ve 6'sı (\%12) YouTube'un öğrenilenleri pekiştirdiğini düşünmektedir. Bu kodlara ilişkin öğretici görüşlerinden bazıları şunlardır:

K2. Türkçe öğretimini olumlu yönde destekleyen bir eğitim materyali olduğunu düşünüyorum.

K4. Derse farklı bir hava katmak, kitapların dışına çıkp eğlenceli etkinlikler yapmak amacı ile kullanılabilir. Elbette bu etkinliklerin planlanarak uygulanması süreç açısından önem teşkil eder.

K14. Görsel işitsel bir materyal olarak motive edici ve destekleyicidir.

K17. Verimli ve eğlenceli bir öğretim ortamı sağlar.

K19. Ö̆̆rencilerin sıklıkla kullandığı bir uygulama YouTube. Her an elimizin altında telefonlar var. Türkçe öğretirken kullanılabilir. Öğrencileri eğlendirecek etkinlikler uygulanabilir.

K27. Teknolojinin derslerde kullanılmasın faydalı buluyorum.

K31. Özellikle A1 seviyesinde, videolarla yeni bir dili öğrenme noktasinda platform motive edici oluyor.

K37. Ders ve ders dışı etkinliklerde, öğrencilerin serbest zamanların verimli geçirmelerini sağlamada yardımcı oluyor.

K39. Bence dinleme etkinlikleri için uygun bir platform. Ayn zamanda dersleri eğlenceli hâle getirip öğrencileri aktif kılıyor.

K50. YouTube, görselliğ in ve sesin aynı ortamda birleştirilebildiğ i muazzam büyüklükte bir ortam. Hem kolay ulaşılabilen hem ücretsiz hem de huzh bir teknolojik saha. Öğrencilerin herhangi bir konu hakkında hedeflenen hangi beceri ise onu geliştirmeye yönelik hazırbulunuşluklarına katkı sağladığı için derslerimde aktif olarak kullanıyorum.

Bilgiyi somut hâle getirme (\%6), interaktif öğrenmeyi sağlama (\%4) ve videolar üzerinden öğrenmeye imkân sunma (\%2) katılımcı görüşlerinden hareketle tespit edilen diğer kodlardır. K48 YouTube'un görsel ve işitsel materyalleri bünyesinde barındırdığını, müziklere ve kliplerine kolayca erişim

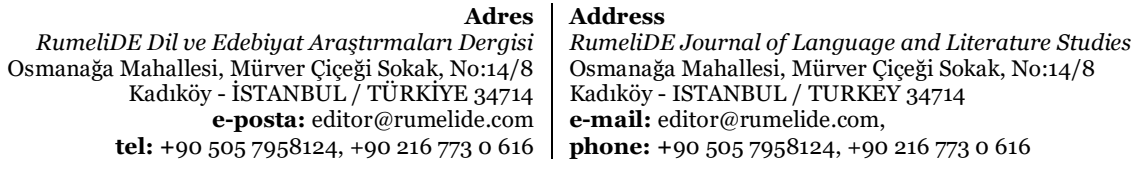


sağlanabildiğini ve bunlar sayesinde ders kitaplarındaki soyut bazı kavramları somut hâle getirmenin mümkün olduğunu düşünmektedir.

K1 YouTube'un videoyla öğretim imkânı sağladığını, örneğin metinde Çanakkale'den bahsediliyorsa şehirle ilgili bilinmesi gerekenleri öğrenicilere izletebildiğini, bu sayede öğrenicilerin şehre gitmeden onun hakkında bilgi sahibi olduklarını, ödüllü kısa filmleri ve alana yönelik hazırlanan videoları da derslerde kullanmanın mümkün olduğunu ifade etmiştir.

K41 platformu kullanırken seçici olmak ve ders içi etkinlikleri planlarken YouTube'dan yararlanmak gerektiğini düşündüğünü, her videonun derslerde kullanılamayacağını, kullanılacak videolarda alt yazı olmasının yararlı olacağını, yabancılara Türkçe öğretimine yönelik videolar hazırlanmasının gerektiğini ifade etmektedir. Ayrıca platformun sadece dil bilgisi değil, dinleme/izleme ve konuşma becerilerinin geliştirilmesinde de önemli olduğunu düşünmektedir.

K43 dijital içeriklerin bir yöntem dâhilinde doğru bir şekilde kullanılması durumunda öğrenicilerin öğrenme yükünü \%50 oranında azaltacağını düşünmekte, fakat mevcut yabancılara Türkçe öğretimi kanallarının yeterli içeriğe sahip olmadıklarını ifade etmektedir.

K5, K10 ve K18 kodlu katılımcılar YouTube'un ücretli hâle gelmesi ve çok fazla reklam olmasının öğrenmeyi olumsuz etkileyeceğini ve öğrenicilerin odaklanma sorunu yaşayabileceğini belirtmektedir.

Katılımcılara yöneltilen "YouTube gelecek yıllarda yabancı dil öğretimi alanını nasıl etkiler? Siz bu konuda neler düşünüyorsunuz?” sorusuna katılımcıların tamamı cevap vermiştir. Öğreticilerin cevapları incelendiğinde YouTube'un şimdi olduğu gibi gelecekte de öğrenme süreçlerine fayda sağlayacağı (K8, K20, K24, K33), bireysel öğrenmenin önem kazanacağı ve insanların ücretsiz olarak kendi kendilerine dil öğrenme imkânı bulacağı (K2, K4, K13, K16, K30), konu üzerinde çalışılarak Yabancılara Türkçe öğretimi amacı güden yeni kanalların açılmasının gerektiği ve bu sayede öğrenmenin sınıf dışına taşınarak kolaylaşacağı (K1, K3, K6, K21, K35, K37) görüşlerinin ön plana çıtı̆̆g görülmüştür.

K30 YouTube'dan dil öğreniminin ücretsiz ve etkili bir yol olduğunu, fakat yabancıların ana dilleri üzerinden Türkçe öğrenmelerinin öğretimi zaman zaman olumsuz etkileyebildiğini ifade etmektedir. K26 Yabancı dil öğretiminin uzun yıllar sınıf ortamından bağımsız olarak düşünülemeyeceğini, temel seviye için sınıf ortamının daha etkili olduğunu, ileri düzey Türkçe eğitiminde veya akademik Türkçe öğretiminde uzaktan eğitim vasıtası olarak YouTube kullanılabileceğini; K48 YouTube’un gelecek yllarda bir düşüş yaşayıp yerine alternatif bir platformun geçeceğini, son zamanlarda artan alakasız reklamların platformun tercih edilirliğini olumsuz etkileyeceğini belirtmiştir.

YouTube'un gelecek yıllarda yabancı dil öğretimi alanını nasıl etkileyeceğine dair diğer öğretici görüşleri ise şu şekildedir:

K41. Uzaktan eğitim çalışmalarında etkili olacağını düşünüyorum. Özellikle Arap öğrencilerin dil bilgisi çeviri yöntemiyle hazırlanmış programların etkisinde kaldı̆̆ı gözlemlemekteyim. Alan uzmanları tarafindan profesyonel bir ekiple hazırlanmış kanallarm artacağın düşünüyorum. Hatta umuyorum. Internetle çok geniş bir alana ulaşabiliyoruz ve artık uzaktan eğitimle dünyanın her yerine, pek çok kişiye ulaşabiliriz. YouTube son yıllarda uzaktan eğitim çalışmalarında hem ulusal sinavlara hem de uluslararası smavlara hazırlanmada etkili bir şekilde kullanilyor. İngilizcenin yabancı dil olaraköğretiminde kullanılan kanalların sayısı ve çeşitliliği incelendiğinde, Türkçenin yabancı dil olarak öğretiminde görev alan bir uzman olarak bu alanda çalışmalarm artması gerektiğini düşünüyorum.

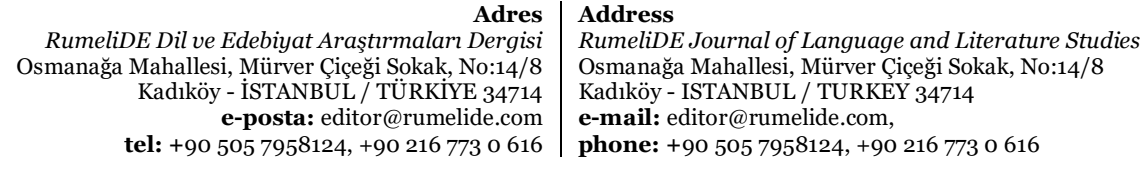


The use of YouTube in language teaching: Experiences and perspectives of those teaching Turkish to foreigners / Ö. Çangal (pp. 63-80)

K43. Bence YouTube dil öğreniminde her türlü görsel ve işitsel materyali bünyesinde bulundurduğundan gün geçtikçe rağbet görecektir. Ancak hiç bir zaman başh bașına bir öğretim aracı olamayacaktır. Bu görüşümün büyük bir iddia olduğunun farkındayım ancak kontrolü zor bir mecra olması ve uzaktan eğitim yapılabilecek birçok programın olması YouTube'un dil öğretiminde yardımcı unsur olarak kalmasına neden olacaktır.

K47. Gelecek yıllarda bu medyanın kullanımının artacağını düşünüyorum çünkü git gide genç nesil ögretmenler yetişiyor ve bu yetişen nesil neredeyse tamamen internetin etkisi altındadır. Öğretmenler genellikle kendileri bir şeyi nasıl öğrendiyse o şekilde öğretme eğilimindedir. Bu sebeple öğrenim hayatında YouTube'dan faydalanan veya YouTube'u sıklkla kullanan bir öğretmen ya da öğretmen adayı bu medyayı derslerinde sıklikla kullanmak isteyecektir. Bu durum da alana hem olumlu hem olumsuz yansiyacaktır. Çünkü sadece bir YouTube videosu izletmek, YouTube'u derslerde kullanmak demek değildir; aynı zamanda o videonun nasıl izletileceği, ne gibi sorular sorulabileceği ve nasıl bir ders işlenebileceğinin bilinmesi gerekir. Bu sebeple yeni nesil öğretmenlerin teknolojinin sınıfta kullanımı hakkında dersler görüp tecrübe edinmesi gerekir, bu da fakültelerdeki akademisyenlerin çağ a ayak uydurma çabasıyla mümkün olabilir.

K50. Dil öğretimi gün geçtikçe gelişmeye devam ediyor. Tahtanın, kalemin, sınıfin yerini alacağımı düşünmüyorum ama dizi ve film izleyerek dil öğrenenler de yadsmamaz derecede fazla. Bu yüzden ders materyali olarak kullanımının dışında kendi kendine bir öğretim aracı bile olabilir. Oradan ders anlatanlar da var ama bütün öğrencileri tutmuyor, öğrenciler on dakika sonra sıkılyor. Bu yüzden bireysel farkhlıklar, ihtiyaçlar ve talepler de bu süreci şekillendirecektir.

$\mathrm{Bu}$ bölümde son olarak öğreticilere eklemek istedikleri görüşlerinin olup olmadığı sorulmuştur. Bu soruya K1 yakında insanların yabancı dil öğrenmesini gerektirmeyen teknolojik gelişmeler olacağı ve öğreticilerin işsiz kalacağı; K10 yabancı dil olarak Türkçe öğretiminin en temel unsurunun öğretmen olduğu, YouTube'un sıradanlaştı̆̆ı, platform üzerinden bir ülkeye ve topluma özel Türkçe öğretimi yapılamayacağı, ülkelere göre kitaplar hazırlanması ve anlatım tarzı belirlenmesi gerektiği şeklinde cevap vermiştir. K37 Yunus Emre Enstitü, YTB ve Maarif Vakfı gibi kurumların YouTube gibi dijital platformlara yönelik hazırlıklar yapması ve bu içeriklerin herkesin kullanımına açık olması gerektiğini düşünmektedir. K43 ise her sosyal medya aracının elbette dil öğretimine elverişli hâle getirilebileceğini, bunun bir program dâhilinde ihtiyaçları karşılayacak şekilde sistemli şekilde yapılması gerektiğini düşünmektedir.

\section{Yabancılara Türkçe öğretenlerin derslerinde YouTube'u kullanma alışkanlıkları nasıldır?}

Araştırmaya katılan öğreticilerin tamamı günlük hayatlarında YouTube’u kullanmaktadır. Öğreticilere platformu kullanım sıklıkları sorulduğunda katılımcıların 23’ü (\%46) genellikle, 21’i (\%42) ara sıra, 4’ü (\%8) her zaman ve 2'si (\%4) nadiren YouTube’u kullandıklarını belirtmiştir. Öğreticiler YouTube'u en çok bilgisayarları (40 öğretici) üzerinden kullanmaktadır. Yine 26 öğretici YouTube’u akıllı telefon, 4 öğretici tablet ve 1 öğretici akıllı televizyon üzerinden kullandıklarını ifade etmiştir. Öğreticilere Türkçe öğretmek amacıyla YouTube'u kullanıp kullanmadıkları sorulduğunda ise katılımcıların 38’i (\%76) "evet”, 12'si (\%24) "hayır" cevabı vermiştir.

Katılımcılara “YouTube kullanılarak en çok hangi beceri(ler) geliştirilebilir?” sorusu yöneltilmiştir. Öğreticilerin verdikleri cevaplar şu şekildedir:

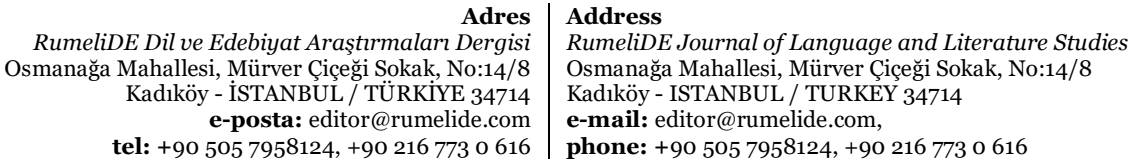

Adres
RumeliDE Dil ve Edebiyat Araşttrmaları Dergisi Kadlë̈ - ̇ürver Çiçegi Sokak, No:14/8 tel: +90 505 7958124, +90 2167730616 


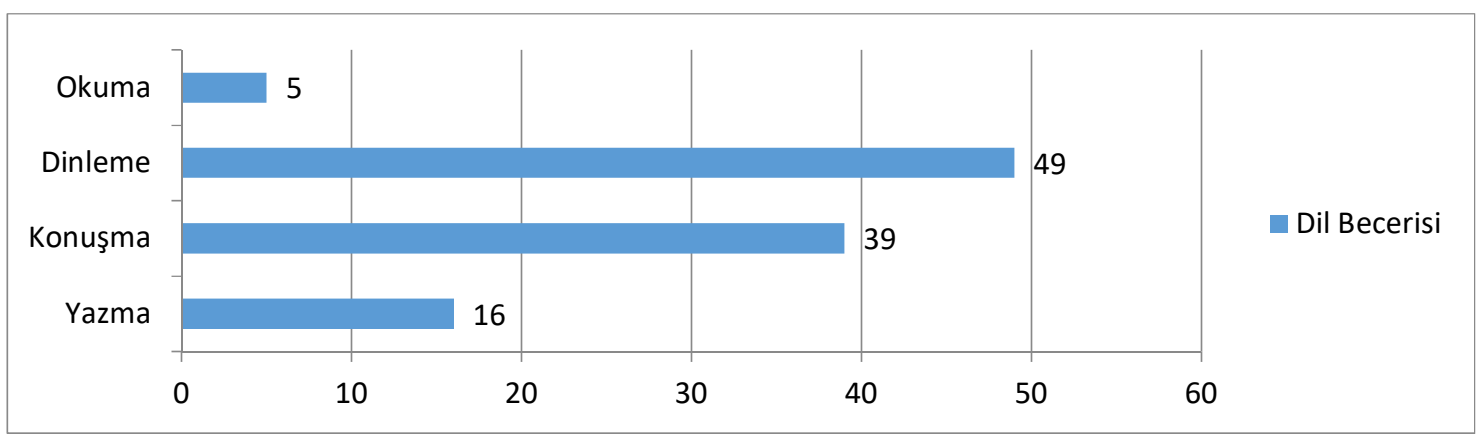

Şekil 1. YouTube Kullanılarak Geliştirebilecek Dil Becerileri

Öğreticilerin 49’u (\%98) dinleme ve 39'u (\%78) konuşma becerisinin YouTube aracıllğı ile geliştirilebileceğini düşünmektedir. Derslerde YouTube'dan yararlanmanın yazmayı geliştireceğini düşünen öğretici sayısı 16 (\%32), okumayı geliştireceğini düşünen ise 5’tir (\%10).

Araştırmada katılımcılara YouTube'un dil becerilerini geliştirmede nasıl kullanılabileceği de sorulmuştur. Öğreticiler genellikle YouTube'un öğrenicilere anlamlı bir girdi sağladığını, bu girdiden hareketle de öğrenicilerin üretici becerilerini geliştirmeye yönelik etkinliklerin gerçekleştirilmesinin mümkün hâle geldiğini belirtmektedir (K2, K3, K13, K17, K23, K27, K32, K36).

Okuma becerisinin geliştirilmesinde görsel okumadan ya da alt yazılı video içeriklerden yararlanılabileceği, dinlenilen şarkıların sözleri öğrenicilere verilerek sözlerin okunmasının istenilebileceği ve video içeriklerden hareketle hazırlanan metinlerin sınıfta okutulabileceği ifade edilmektedir (K1, K28, K29, K40, K47, K50).

Dinleme becerisinin geliştirilmesi ile ilgili çok sayıda öğretici görüş bildirmiştir. Öğreticiler özellikle derslerde karaoke etkinliklerinin düzenlenebileceğini, video içeriklere etkinlik kâ̆̆ıtları hazırlayıp içeriğin dinleme materyali olarak kullanılabileceğini, radyo tiyatrolarından ve şarkılardan derslerde yararlanılabileceğini, şarkı sözlerinde boşlukların olduğu etkinlik kâğıtları ile öğrenicilerin eksik bölümleri tamamlamalarının istenebileceğini düşünmektedir (K1, K12, K20, K21, K36, K38, K48, K50).

Konuşma becerisinin geliştirilmesi için YouTube'da izletilecek video içerikler üzerinden dersin hedeflerine uygun konuşma derslerinin yapılabileceği, öğrenicilere kısa filmler ve videolar izletilerek içerik hakkında öğrenicilerin konuşmalarının sağlanabileceği ve sinema saatleri düzenlenerek öğrenicilerin hem rahatlaması sağlanırken hem de filmi yorumlamalarının istenebileceği öğreticiler tarafından dile getirilmiştir (K12, K21, K30, K31, K41, K45).

Yazma becerisinin geliştirilmesi amacıyla öğrenicilere bir video ya da kısa film izletilip akabinde öğrencilerin bu konu hakkında düşüncelerini kaleme almaları veya öğrenicilerin dinledikleri şarkıların önemli kısımlarını yazmaları (K28) istenebilir. Video içerikler kullanılarak not alarak yazma (K12) ve güdümlü yazma (21) çalışmalarının yapılması, öykü ya da şiir dinletilerek devamının öğrenciler tarafından yazılması (K20), izletilen içeriğin öğrenicilerde uyandırdığı hislerin yazılması (K36), video içeriklerle dikte çalışmalarının yapılması (K31) mümkündür.

Dil becerilerinin geliştirilmesinde YouTube'dan nasıl yararlanılabileceğine ilişkin diğer öğretici görüşleri ise şu şekildedir:

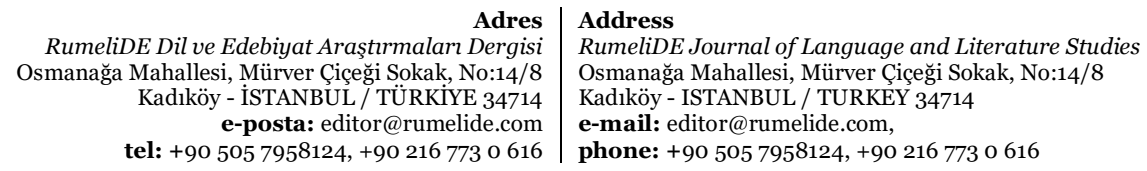


The use of YouTube in language teaching: Experiences and perspectives of those teaching Turkish to foreigners / Ö. Çangal (pp. 63-80)

K1. Videoyu durdurarak soru sorma tekniği ile hem dinleme hem konuşma becerisi geliştirilebilir. Zaten görsel-işitsel materyal olduğu için dinleme becerisi her hâlükârda gelişecektir. Yazma için de sosyal mesaj içeren anlaml bir video ya da kısa film izletilip akabinde öğrencilerin bu konu hakkında düşüncelerini yazmalar istenebilir. Yine öğretici hedefine göre kendi hazırladiğı videoyu da platforma yükleyip çeşitli etkinlikler hazurlayabilir.

K4. Konu ile ilgili kısa videolar, seviyelere göre belirlenecek olan programlar, röportajlar, komik videolar, otantik metinler dinlettirip konuşturma, izlettirip yazdirma şeklinde YouTube'dan yararlanulabilir.

K26. YouTube yabancı dil olarak Türkçe öğrenen öğrencilere en faydalı olacağ beceri konuşma becerisidir. YouTube yayıncllarmın çeşitli videoların izlerken günlük konuşma dilini öğrenebilir. YouTube'un alt yazı veya çeviri özelliğini kullanarak başka bir araca ihtiyacı olmadan dinleme ve konuşma becerisini geliştirebilir.

K31. Özellikle başlangıç seviyelerinde öğrencilerin yeni bir dille tanışıp ses ve telaffuz çalışmalarını sıklıkla yapabilmesi noktasında yardımc olur. Çeşitli zamanları öğrenimi ve kullanımı noktasında özellikle hikâye ve şarkılardan faydalanılabilir. Sinema saatleri düzenlenerek öğrencilerin hem rahatlaması hem de dinleme ve konuşma becerilerinin geliştirilmesi sağlanabilir. Öğrenci örnek bir metni dikte yöntemiyle YouTube üzerinden dinleyip yazma etkinliğini uygulayabilir. Sürecin sonunda da metni kontrol etme imkânı bulabilir.

K41. Dersteki konularla ilgili yazma ve konuşma etkinlikleri için animasyon veya kısa filmler izletilerek beyin firtınası yapılır ve sonrasında öğrenciler kendi yazma ve konuşma çalışmalarım planlayabilirler. Kültür aktartmı açısından uygun videolarla kültürümüze ait değerler aktarllabilir. Türk büyükleri ile ilgili TRT Okul kanalından videolar izletilebilir.

K5o. Okuma becerisi için derse hazırlık noktasında ders metni ile ilgili video içeriklerden yararlanılır. Örneğ in festivallerle ilgili bir video izlettikten sonra soru-cevaplar etkinliği düzenlenir ve ardından okuma metnine geçilir. Bu öğrencide konuyu kavrama ve kelimeleri anlamlandırmaya yardımcı olur. Dinleme becerisi için genellikle bir şarkı metninin öğrencilere dağıtılıp kâğıttaki boşlukları dinlediklerine göre yazmaları istenebilir. Bir film, kısa film, video izlenirken durdurulup çeşitli sorular sorularak dinleme anlama takip edilebilir. Konuşma becerisi için öğrenici izlenilenler hakkında konuşturulabilir. Yahut öğretici tarafindan seçilen bir video öğrencilere izlettirilerek öğrencilerce seslendirilmesi istenebilir. Tekerleme örnekleri, şarkı örnekleri dinlettirilip telaffuz çalışmaları yapılabilir. Yazma becerisi için kültürel farklılılar, kültür tanıtımı noktasında ön bilgi hazırladıktan sonra seçilen videolar izlenir ve o konu ile ilgili öğrencilere yazı yazdırılabilir.

Araştırma kapsamında ele alınan bir diğer husus öğreticilerin YouTube’u derslerinde hangi durumlarda kullanmayı tercih ettikleridir. Bu kapsamda öğreticilere "Ders sürecinde en çok hangi durumlarda YouTube videolarından faydalanıyorsunuz?” sorusu yöneltilmiştir. Öğreticilerin verdikleri cevaplar 6 farklı kod altında toplanmıştır. Öğreticilerin derslerde YouTube kullandıkları durumlara ilişkin frekans ve yüzdeler şu şekildedir:

Tablo 3. Öğreticilerin Derslerde YouTube Kullandıkları Durumlara İlişkin Frekans ve Yüzdeler

\begin{tabular}{llll}
\hline Tema & Kodlar & $\mathbf{f}$ & \% \\
\hline & Dinleme etkinlikleri yaptırma & 11 & 22 \\
& Dil bilgisi yapılarını pekiştirme & 10 & 20 \\
Öğreticilerin derslerinde YouTube’u & Konuşma etkinlikleri yaptırma & 9 & 18 \\
Kullandıkları Durumlar & Yazma etkinlikleri yaptırma & 9 & 18 \\
& Kültürel değerleri tanıtma & 8 & 16 \\
& Öğrenicilerin dikkatlerini toplama & 3 & 6 \\
\hline & Toplam & $\mathbf{5 0}$ & $\mathbf{1 0 0}$ \\
\hline
\end{tabular}

Öğreticiler YouTube’u dinleme etkinliklerini yaptırma (\%22), dil bilgisi yapılarını pekiştirme (\%20), konuşma etkinliklerini yaptırma (\%18), yazma etkinliklerini yaptırma (\%18), kültürel değerleri tanıtma

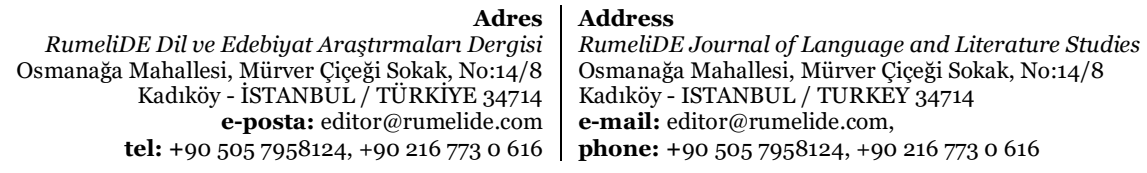


Dil öğretiminde YouTube’un kullanımı: Yabancılara Türkçe öğretenlerin deneyimleri ve bakış açıları / Ö. Çangal (63-80. s.)

(\%16) ve öğrenicilerin dikkatlerini toplama (\%6) amacıyla derslerde kullandıklarını belirtmektedir. Öğretici görüşlerinden bazıları şu şekildedir:

K1. Genellikle kültürel bir ögeyi ya da bir yeri tanıtırken YouTube’u kullanıyorum. Öğrenicilerle karaoke oyunları oynuyoruz. Bazen de yazınsal türlerin film ya da çizgi filmlerini izletiyorum. Bunun dışında dil bilgisi yapısına uygun bir film bulursam izletiyorum. Ayrıca konuşma kulüplerinde de slkça YouTube'dan yararlanıyorum.

K3. Dinleme becerisinin gelişmesi veya gramer konularını daha akılda kahıı olması için faydalaniyoruz.

K4. Özellikle konuşma ve yazma becerisinin gelişimine yönelik işlenen konu ile ilgili farkh ve eğlenceli videolar buluyorum, derslerinde kullanıyorum. Sinıfin büyük çoğunluğu bu etkinliklerden memnun kaliyor.

K9. Türkoloji alan dersleri ve yabancllara Türkçe öğretim setleri içerisinde tarih, coğrafya ve özellikle Türk kültürünü içeren kısımlar ile ilgili Türkçe belgesellerden, dil bilgisi konularının pekişstirilmesini sağlayan şarkılardan, becerilerinin gelişmesi için belirlenen filmlerden faydalanmaktayım.

K12. Konuşma, yazma etkinliklerinde ve kültür ile ilgili konuların anlatımında kullanıyorum.

K13. Karşıtlk ve koşutluk bildiren gramer yapılarında kullanıyorum.

K19. SSarka ve şür dinletiyorum. Film izletiyorum. Sonra üzerine konuşuyoruz ya da yazıyoruz. Bir şarkıda geçen yeni öğrendiğimiz ekleri soruyorum.

K23. Konuyla alakah video izleteceğim zaman ya da konuşma becerisini geliştirmek için YouTube'u kullanyorum.

K28. Hemen hemen her gramere uygun bir şarkı var. Gramerden sonra şarkıyı dinletiyorum. Kısa masallar ya da hikâyeler izletiyorum. Türk kültürüyle ilgili bilgi vermek amacıyla izletiyorum. Yemek tarifleri veya belgeseller izletiyorum.

K33. Dinleme metinlerini YouTube'dan açıorum. Sessiz bir animasyon izlettirip süreci yazmalarm istiyorum. Masallar dinlettirip soru hazırlamalarmı istiyorum.

K41. Ders anında değil fakat ders planı hazırlarken belirlediğim videoları dinleme etkinlikleri hazırlamada, konuşma ve yazma çalışmalarına hazırlık aşamasında kullanıyorum.

K42. Genellikle bir yere, bir kültüre ait göstermemiz gereken özel bir şey varsa faydalanıyorum.

K43. Dinleme/izleme ve konuşma becerisine yönelik çalşmalarda YouTube’u kullanmaktayım. Sessiz filmler konuşma becerisine yönelik etkinliklerde; şarkl, film, dizi, biyografi gibi türler ise dinleme ve yazma etkinliklerinde sıklkla başvurduğum türlerdir. Ayrıca TRT arşivine ait videolarda insanlar İstanbul Türkçesi ile konuştuğundan bunlar üzerinden öğrettiğimiz dilin pekiştirilmesi daha da kolay olmaktadır.

Katılımcılara bu bölümde son olarak takip ettikleri yabancılara Türkçe öğretimi kanalları olup olmadığı sorulmuştur. Öğreticilerin takip ettikleri kanallara ilişkin frekans ve yüzdeler şu şekildedir:

Tablo 4. Öğreticilerin Takip Ettikleri Türkçe Öğretimi Kanallarına İlişkin Frekans ve Yüzdeler

\begin{tabular}{|c|c|c|c|c|}
\hline Tema & \multicolumn{2}{|l|}{ Kodlar } & $\mathbf{f}$ & $\%$ \\
\hline \multirow{7}{*}{$\begin{array}{l}\text { Öğreticiler tarafindan takip edilen } \\
\text { Türkçe öğretimi kanalları }\end{array}$} & \multicolumn{2}{|l|}{ Yok } & 20 & 40 \\
\hline & \multicolumn{2}{|l|}{ Hep Türkçe } & 12 & 24 \\
\hline & \multicolumn{2}{|l|}{ Önder Çangal } & 4 & 8 \\
\hline & \multicolumn{2}{|c|}{3 Dakikada Türkçe } & 4 & 8 \\
\hline & \multicolumn{2}{|c|}{ Yunus Emre Enstitüsü } & 3 & 6 \\
\hline & \multicolumn{2}{|c|}{ Açıköğretim Sistemi - Anadolu Üniversitesi } & 3 & 6 \\
\hline & \multicolumn{2}{|c|}{ Türkçe öğreniyorum } & 2 & 4 \\
\hline \multicolumn{2}{|c|}{$\begin{array}{r}\text { Adres } \\
\text { RumeliDE Dil ve Edebiyat Araștrmaları Dergisi } \\
\text { Osmanağa Mahallesi, Mürver Ciçeği Sokak, No:14/8 } \\
\text { Kadıköy - İSTANBUL / TÜRKIYE } 34714\end{array}$} & $\begin{array}{l}\text { Address } \\
\text { RumeliDE Journal of Language and } \\
\text { Osmanağa Mahallesi, Mürver Cicceği } \\
\text { Kadıköy - ISTANBUL / TURKEY } 347 \\
\text { e-mail: editor@rumelide.com, } \\
\text { phone: +90 505 7958124, +90 } 2167\end{array}$ & & \\
\hline
\end{tabular}


The use of YouTube in language teaching: Experiences and perspectives of those teaching Turkish to foreigners / Ö. Çangal (pp. $63-80)$

\begin{tabular}{lll} 
So Turkish & 1 & 2 \\
Gürkan Bilgisu & 1 & 2 \\
Toplam & $\mathbf{5 0}$ & $\mathbf{1 0 0}$ \\
\hline
\end{tabular}

Katılımcıların 20’si özellikle takip ettikleri YouTube kanallarının olmadığını ifade etmiştir. Bunun dışında öğreticilerden 12'si "Hep Türkçe”, 4’ü “Önder Çangal”, 4’ü “3 Dakikada Türkçe”, 3’ü "Yunus Emre Enstitüsü” ve 3’ü "Açıöğretim Sistemi - Anadolu Üniversitesi” kanallarını takip etmektedir. "Gürkan Bilgisu” ve “So Turkish” kanalları ise 1'er öğretici tarafından takip edilmektedir.

\section{Yabancılara Türkçe öğretiminde YouTube kullanımının olumlu ve olumsuz yönleri nelerdir?}

Yabancllara Türkçe öğretiminde YouTube kullanımının olumlu ve olumsuz yönlerini tespit edebilmek amacıyla katılımcılara iki açık uçlu soru yöneltilmiştir. YouTube’un dil öğretim süreçlerinde kullanımının olumlu yönlerine ilişkin frekans ve yüzdeler şu şekildedir:

Tablo 5. Yabancılara Türkçe Öğretiminde YouTube Kullanımının Olumlu Yönlerine İlişkin Frekans ve Yüzdeler

\begin{tabular}{llll}
\hline Tema & Kodlar & f & \% \\
\hline & Dil becerilerini geliştirme & 11 & 22 \\
& Öğrenmeyi eğlenceli hâle getirme & 8 & 16 \\
& Otantik içerik sunma & 6 & 12 \\
& Odaklanmayı artırma & 5 & 10 \\
& Bilgiye kolay ulaşma & 4 & 8 \\
Yabancılara Türkçe öğretiminde YouTube & Öğrenme motivasyonunu artırma & 4 & 8 \\
kullanımının olumlu yönleri & Öğrenmeyi kolaylaştırma & 3 & 6 \\
& Söz varlı̆̆ını zenginleştirme & 3 & 6 \\
& Doğal dil kullanımını gösterme & 2 & 4 \\
& Hedef dile maruz bırakma & 2 & 4 \\
\hline
\end{tabular}

Öğreticilerin yüzde 22'si YouTube'un dil becerilerinin gelişimine katkı sağladığını, yüzde 16'sı öğrenmeyi eğlenceli hâle getirdiğini, yüzde 12'si öğrenicilere otantik içerikler sunduğunu ve yüzde 10'u odaklanmayı artırdığını düşünmektedir. İlk dört kod ile ilgili öğretici görüşlerinden bazıları şu şekildedir:

K1. Öğrencilerin sezerek ve eğlenerek öğrenmesine yardımcı oluyor. Özellikle çocuk gruplarında daha sık kullanabiliyoruz.

K2. Farklı kişilerin konuşmasını barındıran videolar sayesinde YouTube'un dinleme, konuşma becerilerini ve söz varlı̆̆ı geliştirdiğ ini düşünüyorum.

K5. Öğrenci farklı otantik söylemlerle karşılaşır. Böylece dinleme/izleme becerisi gelişir. Ayrıca izlenen videonun ardından yapılan konuşma ve yazma çalışmaları da çok faydah olur.

K6. Öğrenciyi rutin kitap bağımlıh̆̆ından kurtarıyor, daha keyifli ve faydalı zaman geçirdiğimizi düşünüyorum.

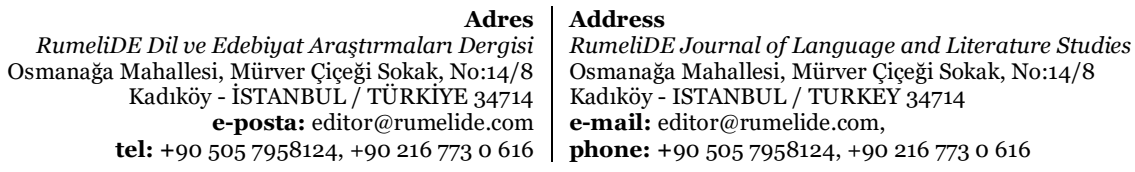


Dil öğretiminde YouTube’un kullanımı: Yabancılara Türkçe öğretenlerin deneyimleri ve bakış açıları / Ö. Çangal (63-80. s.)

K9. Bulundukları ülkede Türkçeyi günlük hayatta pratik yaparak geliştirme imkânı olmayanlar için internetin dört beceriye yönelik, YouTube'un özellikle dinleme ve konuşmaya yönelik olumlu etkisi olduğunu düşünmekteyim.

K2o. Birden fazla beceriyi geliştirecek etkinlikler yapılabilir. Öğrencinin ilgi ve dikkatini çekebilir.

K21. Öğrencileri pek çok konuda farkh düşüncelere itebilecek materyaller bulunmaktadır. Sözgelimi, konuşma becerisinin geliştirilmesi açısından kısa filmler izletilebilmekte ve bunların öğrenciler tarafindan yorumlanabilmesi sağlanmaktadır.

K23. Dinleme ve konuşma becerisini geliştirici, eğlenceli videolarla öğrencilerin derse katılımını arttırıcı özellikleri bulunmaktadır

K28. Öğrenciler Türkçe şarkı ve film önerisi istiyorlar. Bu noktada kur seviyesine uygun şarkılar ve filmler izletilmesi onların dikkatini çekiyor ve derse ilgileri artıyor.

K33. Dinleme becerisi için çok önemli olduğunu düşünüyorum. Aynı zamanda öğrencilere şarkı ve masal öğretiminde kullanıyorum. Nasreddin hoca fikralarmı ve Hacivat-Karagöz oyunların izleterek kültür aktarımı yapıyoruz.

K40. Öğretmenin derse olan ilgiyi artırmasımı sağlıyor. Ö̆̆renci açısından ĕ̆lenerek öğrenmeyi aktifleştiriyor.

YouTube’un bilgiye kolaylıkla ulaşılmasını sağladığını ve öğrenme motivasyonunu artırdığını düşünen 4'er katılımcı, öğrenmeyi kolaylaştırdığını ve öğrenicinin söz varlığını zenginleştirdiğini düşünen 3’er katılımcı bulunmaktadır. Söz konusu kodlara ilişkin öğretici görüşlerinden bazıları şu şekildedir:

K11. Derse zenginlik katıyor, özgün malzeme sağlıyor ve motivasyonu artırıor.

K17. Erişilmek istenilen şarkı, film, kısa film gibi öğretim materyali olarak kullanılabilecek dokümanlara kolayca ulaşılmasını sağlamaktadır.

K27. Öğrencilerin derse ilgisini artırıyor. Derse güdülenmeyi sağlıyor.

K36. Sözcük öğretiminde, konuşma becerisi kazandırmada ve kültür aktarımı konusunda faydalı olduğunu düşünüyorum.

YouTube içerikleri sayesinde öğrenicilere doğal dil kullanımını gösterme, onları hedef dile maruz bırakma ve kültürel etkileşim sağlama kodlarına ilişkin 2'şer öğretici görüş bildirmiştir.

K12 YouTube'da gerçek dünyadan kesitlere ulaşmanın mümkün olduğunu, bu sayede Türkçenin doğal kullanımının öğrenicilere gösterilebileceğini; K43 öğrenicinin görsel ögelerle dili bağlamında gördüğünü, daha hızlı ilerleme kaydettiğini, başlangıç düzeyindeki öğrenicilerde videoyu yavaşlatma seçeneği sayesinde öğrenicilerin telaffuzlarının geliştiğini ve hedef kitleyi Z kuşağının oluşturduğu düşünüldüğünde YouTube'un vazgeçilemeyecek bir öğretim aracı olduğunu belirtmiştir.

K37 YouTube'un öğrencileri serbest zamanlarında hedef dille meşgul etmesi nedeniyle yararl olduğunu, K24 ise kültürel etkileşimi sağlamada YouTube'dan yararlandığını belirtmiştir. Yabancılara Türkçe öğretiminde YouTube kullanımının olumlu yönleri ile ilgili K5o kodlu öğreticinin görüşü ise şu şekildedir:

Dil öğretiminde karşılaşılan en büyük sorunlardan biri farklı ülkelerden gelen öğrencilerin farkh hazırbulunuşluk düzeylerine sahip olmasıdır. Onları ortak bir düzeye getirebilmek için derse hazırlk sürecini genişleterek işlerim. Böylece bir konu hakkında vermek istediğim kelime, kalıp ifade ve yapı hakkında bilgiyi somutlaştıracak bir materyali YouTube'da bulursam mutlaka kullanırım. Bu sayede uzun uzun anlatacağım bir konuyu daha somut, daha hızh, görsellerle veya sesle destekleyerek vermiş olurum. Bu da bana öğrencilerin eşit düzeye gelmesinde büyük bir zaman tasarrufu sağlar.

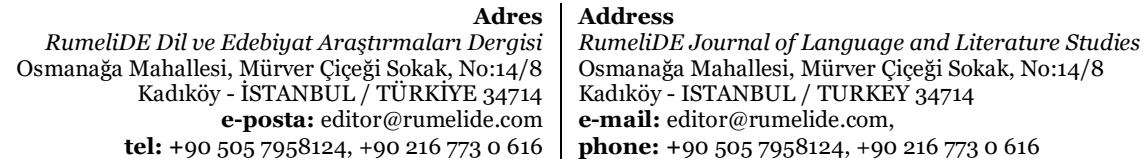

Adres
RumeliDE Dil ve Edebiyat Araştırmaları Dergisi tel: +90 $5057958124,+902167730616$

phone: +90 505 7958124, +90 2167730616 
The use of YouTube in language teaching: Experiences and perspectives of those teaching Turkish to foreigners / Ö. Çangal (pp. 63-80)

Katılımcllara yöneltilen "Size göre Türkçe öğretirken YouTube kullanılmasının olumsuz yönleri nelerdir?” sorusuna 10 öğretici "Dil öğretim süreçlerinde YouTube'dan yararlanmanın herhangi bir olumsuz yönü yoktur.” şeklinde cevap vermiştir. Geri kalan 40 katılımcının soruya verdikleri cevaplardan elde edilen veriler 7 farklı kod altında toplanmıştır.

YouTube'un yabancılara Türkçe öğretimi süreçlerinde kullanımının olumsuz yönlerine ilişkin frekans ve yüzdeler ise şu şekildedir:

Tablo 6. Yabancllara Türkçe Öğretiminde YouTube Kullanımının Olumsuz Yönlerine İlişkin Frekans ve Yüzdeler

\begin{tabular}{llll}
\hline Tema & Kodlar & $\mathbf{f}$ & $\mathbf{\%}$ \\
\hline & Yanlış öğrenmelere neden olma & 11 & 22 \\
& Olumsuz yönü yok & 10 & 20 \\
& Öğrenicilerin dikkatini dağıtma & 9 & 18 \\
Yabancılara Türkçe öğretiminde YouTube & Reklam ve uygunsuz içerikleri gösterme & 7 & 14 \\
kullanımının olumsuz yönleri & Ön hazırlık gerektirmesi & 6 & 12 \\
& Zaman kaybına neden olma & 4 & 8 \\
& Düzeye uygun video seçiminin zor olması & 2 & 4 \\
& Öğreticiye soru sorulamaması & 1 & 2 \\
\hline
\end{tabular}

Katılımcılara göre yabancılara Türkçe öğretimi süreçlerinde YouTube kullanımının en olumsuz yönü platformun yanlış öğrenmelere neden olmasıdır (\%22). Koda ilişkin öğretici görüşlerinden bazıları şu şekildedir:

K21. Çocuklarm kültürel, ahlaki ve dil gelişimini dikkate alacak şekilde yeterince denetlenmediğinden ve kontrol altına alınamayan bir sosyal ă̆ olduğu için öğrencilerin Türk dili ve kültürü alanında yanlış fikirler edinmesine imkân sağlayabilecek bir yer.

K26. YouTube'un herkese açık olması dolayısıyla öğrencilerin hangi kanalda ne öğrenebileceği önceden bilinememektedir. İşin ehli olmayanlarm da bu sürece dâhil olduğu göz önüne alınırsa kanal seçiminde öğrencilerin iyi yönlendirilmesi gerekmektedir. Çeşitli yayınclarm YouTube'da ölçünlü dilde konuşmadiğı platformda video izleyen herkes tarafindan bilinmektedir. Bu yüzden YouTube'da yayınlanan her materyal yabancılara Türkçe öğretimi sürecinde bize fayda sağlamamaktadır.

K31. Öğrencilerin YouTube'daki hatah Türkçe ders anlatım videolarına ulaşıp eksik ve hatah öğrenme gerçekleştirmeleri.

K37. Muhakkak yönlendirme yapılmal, yoksa argo, küfür vb. standart dilin dışında olumsuzlarla birlikte Türk kültürünün de yanlış tanınmasına sebep olabiliyor.

K49. Bazı içeriklerin olumsuzluklarıyla karşı karşıya kahnıyor. Bazen yanlış anlaşılmalara sebep olabiliyor.

Katılımcıların yüzde 18 'i YouTube'un öğrenicilerin dikkatlerini dağıttığını, yüzde 14'ü kullanım sırasında reklam ve uygunsuz içeriklerle karşılaşıldığını, yüzde 12'si derste YouTube'dan yararlanmak için ön hazırlık yapmak gerektiğini, yüzde 8’i uygulamanın zaman kaybına neden olduğunu, yüzde 4’ü düzeye uygun video seçiminin kolay olmadığını ve yüzde 2'si öğrenicinin soru sorabileceği bir muhatap bulamadığını belirtmiştir.

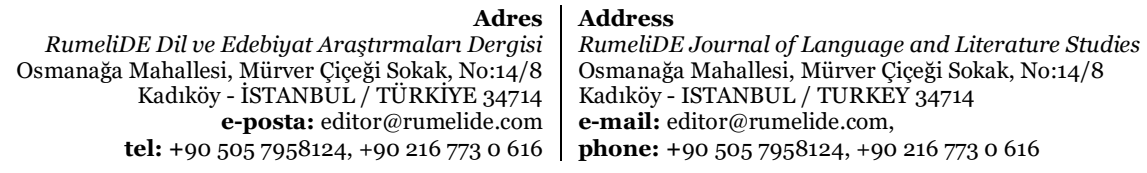


K3 YouTube'un fazla izlendiğinde öğrenicilerin dikkatlerini dağıttığını ifade etmiştir. K4 YouTube üzerinden gerçekleştirilecek etkinliklerin öğrenciler tarafından ders dışı etkinlik olarak algılanıp ciddiye alınmayacağını, bu durumun onların dikkatlerini dağıtacağını düşünmektedir. K3o ise video sırasında öğrenicilerin dağıldığını ve derse odaklanma problemleri yaşadıklarını aktarmıştır.

K1 YouTube’u kullanırken sürekli olarak reklamlarla karşılaştığını, K5 uygulamayı kullanırken hazırlıksız yakalanılması durumunda uygunsuz içerik ve reklamların öğrenicileri rahatsız edeceğini, K18 uygulamanın reklamsız sürümünün ücretli olduğunu ve bu nedenle sürekli olarak derste reklamların çıktı̆̆ını, $\mathbf{K 4 8}$ alakasız reklamların konu bütünlüğünü bozabildiğini ifade etmektedir.

K28 uygun içerikler seçildiğinde uygulamanın zararı olmayacağını, fakat öğretim elemanının dersten önce içerikleri izlemesi ve daha sonra derste kullanması gerektiğini belirtmiştir. Konuyla ilgili olarak K50 derse uygun içerik bulmanın çok zor olduğunu, öğrenicilere uygun videoları bulmak için zaman ve emek harcadığını, dolayısıyla YouTube'dan yararlanmak isteyenlerin dersten önce hazırlık yapması ve dersi bu doğrultuda yürütmesi gerektiğini ifade etmiştir.

YouTube kullanımında aşırıya kaçıldığında öğreniciler dersi kaynatabilmekte (K22), öğreniciler videoları kendi cep telefonlarından izlediklerinde başka videolara geçerek zaman kaybedebilmektedir (K23). K19 da konuyla ilgili olarak öğrencilerin uygulamada farklı videolara dalmalarının zaman kaybına neden olacağını, etkinliği ciddiye almamaları durumunda başarısız olacaklarını, öğrenicilerin derslerde sürekli olarak YouTube'dan video izlemek istediklerinde dersin akışının bozulacağını düşünmektedir.

\section{Sonuç}

Geleneksel dil öğretim yöntemleri günümüzde çok fazla kullanılmamakta, hazırlanan dil öğretim programları modern dil öğretim yöntemlerinin kullanılmasını ve öğrenicinin öğrenmenin merkezine alınmasını önermektedir. Bu süreçte öğrenicilerin motivasyonlarını yüksek tutmak, eğlenerek öğrenmelerini sağlamak ve birden fazla duyu organına hitap ederek öğrenmeyi kalıcı kılmak gerekmektedir. $\mathrm{Bu}$ bağlamda derslerde teknolojik araçlardan, internetten ve sosyal medyadan yararlanmak öğreticinin işini kolaylaştıracaktır.

Günümüzde insanlar zamanlarının önemli bir kısmını çeşitli internet sitelerinde geçirmekte, sosyal medya araçları üzerinden etkileşim kurma imkânı bulmaktadır. Sosyal medyadaki doğal etkileşim ortamları ve otantik içerikler, sosyal medyayı dil öğretim süreçlerinde kullanılacak önemli bir araç hâline getirmektedir. Nitekim sosyal medya araçlarının dil öğretim süreçlerinde kullanılması ile ilgili çok sayıda çalışma gerçekleştirilmiştir (bk. Alhamami, 2013; Al-Ali, 2014; Balçıanlı, 2009; Berk, 2009; Fachriyah vd., 2020; Kbooha \& Elyas, 2018; Kim \& Kim, 2021; Pujiati vd., 2019; Renaldi, 2017; Shariff \& Shah, 2019). Yapılan çalışmalar sosyal medyanın dil öğretiminde kullanıldığında öğrenmeyi kolaylaştırdığını, ders dışı süreçlerde de öğrenicilerin hedef dile maruz kalmasını sağladığını, hedef dil konuşucuları ile öğrenicilerin iletişim kurma ve pratik yapma imkânı bulduklarını ortaya koymaktadır. YouTube'un yabancılara Türkçe öğretiminde kullanımına yönelik öğretici görüsslerine dayanan bu araştırmadan elde edilen veriler de önceki araştırmaların sonuçlarını desteklemektedir.

Çalışma grubunda yer alan öğreticiler; YouTube’un dil becerilerini geliştirdiğini, soyut yapıtları somutlaştırdığını, öğrenilenleri pekiştirdiğini, öğrenicilerin eğlenerek öğrenme imkânı bulduğunu ve bu yönüyle öğrenmeyi desteklediği için sürece fayda sağladığını düşünmektedir. Aynı öğreticiler gelecekte

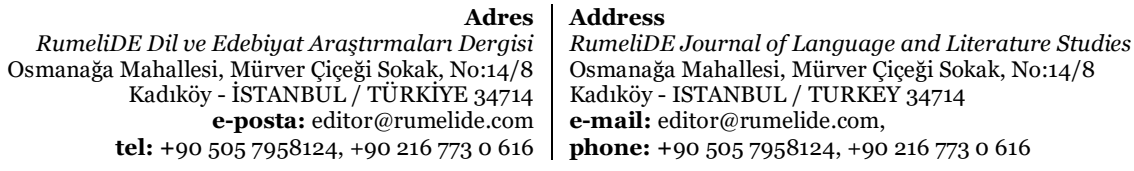


The use of YouTube in language teaching: Experiences and perspectives of those teaching Turkish to foreigners / Ö. Çangal (pp. 63-80)

bireysel öğrenme sistemlerinin geliştirileceğini ve dil öğretiminde YouTube kullanımının artacağını ifade etmekte, öğrenmeyi sınıf dışına taşıma imkânı veren YouTube kanallarının sayısının artması gerektĭgini belirtmektedir.

Yabancllara Türkçe öğretiminde dört temel dil becerisi olarak da adlandırılan okuma, dinleme, konuşma ve yazmanın geliştirilmesi temel amaçtır. Bu bağlamda öğreticilere derslerde YouTube’u kullanarak öğrenicilerin hangi becerilerinin geliştirilebileceği sorulduğunda özellikle dinleme ve konuşma becerilerinin geliştirilmesinde YouTube'un çok faydalı olduğu, yazma ve okuma becerisinin geliştirilmesinde ise uygulamadan daha az yararlanılabileceği ifade edilmiştir.

Öğreticiler derslerde konuşma, yazma ve dinleme etkinlikleri yaptırırken YouTube’u kullanmakta, video içerikleri kullanarak hem anlatılan dil bilgisi yapılarını pekiştirme hem de Türk kültürüne ait unsurları öğrenicilere tanıtma imkânı bulmaktadır. Dikkati dağılan öğrenicilerin derse odaklanmalarının sağlanmasında da YouTube etkili bir araç olarak ön plana çıkmaktadır. Öğreticiler yabancılara Türkçe öğretimi süreçlerinde kullanılmak üzere içerik hazırlayan "Hep Türkçe, Önder Çangal, 3 Dakikada Türkçe, Yunus Emre Enstitüsü, Anadolu Üniversitesi Açıköğretim Sistemi ve Türkçe öğreniyorum” kanallarını takip etmektedir.

Dil öğretiminde YouTube kullanımının hem olumlu hem de olumsuz yönleri bulunmaktadır. YouTube’u derslerde kullanmanın olumlu yönleri şu şekildedir:

1. YouTube dil becerilerini geliştirir,

2. Öğrenmeyi eğlenceli hâle getirir,

3. Otantik içerikler sunar,

4. Odaklanmayı ve motivasyonu artırır,

5. Bilgiye kolay ulaşma imkânı verir,

6. Söz varlığını zenginleştirir,

7. Doğal dil kullanımlarını gösterir,

8. Kültürel etkileşim sağlar,

9. Öğreniciyi hedef dile maruz birakır.

Duisembekova (2014, s. 78-79) çocuklara İngilizce öğretirken YouTube kullanıldığında çocukların başarı duygusunu tatma imkânı bulduklarını, şarkıların motivasyonlarını yükselttiğini, doğru telaffuz kazandırmada ve tonlama alıştırmaları yapmada YouTube'un etkili olduğunu belirtmiştir. Bastos ve Ramos’a (2009, s. 2089) göre YouTube'daki videolarla zenginleştirilmiş derslerde öğreniciler sürece katılmaya daha istekli olmakta, dil sorunlarıyla uğraşanlar özgüvenlerini geri kazanmakta ve YouTube öğrenicileri derslere katılmaya teşvik etmektedir. Video içerikler kelimelerin özümsenmesini kolaylaştırmakta, öğrenicilerde farklı bakış açılarının geliştirilmesine destek olmaktadır. Catapano'ya (2016) göre de YouTube öğreticilerin kendilerini geliştirebilecekleri önemli bir yerdir. Ayrıca internete

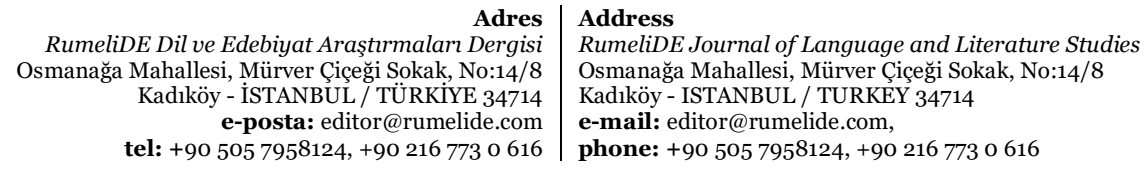


erişimin olduğu her yerde öğreniciler videoları izleyebilir, faydalı buldukları videoları arkadaşları ve öğretmenleri ile paylaşabilirler.

Olumlu yönleri daha fazla olmakla birlikte YouTube'un dil öğretiminde kullanımının bazı olumsuz yönleri de bulunmaktadır. Öğreticilere göre YouTube yanlış öğrenmeye neden olabilmekte, kontrol edilmediği durumlarda öğrenicilerin dikkatini dağıtmakta ve bu nedenle zaman kaybına neden olmaktadır. Düzeye uygun içeriklerin seçilmesi ve ön hazırlık gerektirmesi YouTube kullanımında öğreticilerin karşılaştıkları zorluklar olarak dikkat çekerken öğreticiye soru sorulamaması, süreçte reklam ve konuyla ilgisiz içeriklerle karşılaşılması öğrenicilerin karşılaştıkları sorunlar olarak ortaya çıkmaktadır. Voices (2020) da YouTube'daki tüm videolarda doğru bilgi bulunmadığını, bazı içeriklerin tüm yaş gruplarına uygun olmadı̆̆ını, internete erişim sorunlarının YouTube’u kullanmaya engel olabileceğini ve uygulamada çok fazla reklamla karşılaşıldığını ifade etmektedir.

Çalışma sonuçları yabancılara Türkçe öğretiminde YouTube kullanımının öğrenme süreçlerine olumlu yönde etki ettiğini ortaya koymaktadır. Bu da öğreticilerin derslerinde YouTube, Instagram ve WhatsApp gibi araçlardan yararlanmasının bir gereklilik olduğunu göstermektedir. Çalışma sonuçlarından ve benzer çalışmalardan hareketle yabancılara Türkçe öğretiminde YouTube kullanımı ile ilgili hazırlanan öneriler şu şekildedir:

1. Öğreticiler gerek ders içi gerekse ders dışı süreçlerde YouTube'daki otantik içeriklerden yararlanmalıdır.

2. Kullanılacak olan içerikler önceden tespit edilmeli, öğrenme amaçlarına veya hedef kitlenin hassasiyetlerine uygun olmayan videolar derslerde kullanılmamalıdır.

3. Öğreticiler derslerinde özellikle dil bilgisi yapılarının pekiştirilmesinde YouTube'daki şarkıları kullanmalı, şarkıların ezgili olma özelliği sayesinde dinleme becerisinin geliştirilmesi de sağlanmalıdır.

4. Türk kültürünü yansıtan videolar ve kanallar tespit edilerek öğrenicilerle paylaşılmalıdır.

5. Yabancılara Türkçe öğretimi ile ilgili içerik üreten kanallar tespit edilerek öğrenicilerin bu kanalları takip etmeleri tavsiye edilmelidir.

6. YouTube'daki videolar aracılı̆̆ılla öğrenicilere anlamlı girdi sağlanmalı, öğreniciler izledikleri/dinledikleri videolardan hareketle konuşma veya yazma çalışmaları yapmalıdır.

7. Öğrenicilere YouTube’u dil öğrenimi amacıyla kullanma alışkanlığı kazandırılmalıdır.

\section{Kaynakça}

Al-Ali, S. (2014). Embracing the selfie craze: Exploring the possible use of Instagram as a language mLearning tool. Issues and Trends in Educational Technology, 2(2), 1-16.

Alhamami, M. (2013) Observation of YouTube language learning videos. Teaching English with Technology, 13(3), 3-17.

Ayu, L. P. (2016). YouTube videos in Teaching listening: The benefits in experts' views. Research in English and Education (READ), 1(2), 152-160.

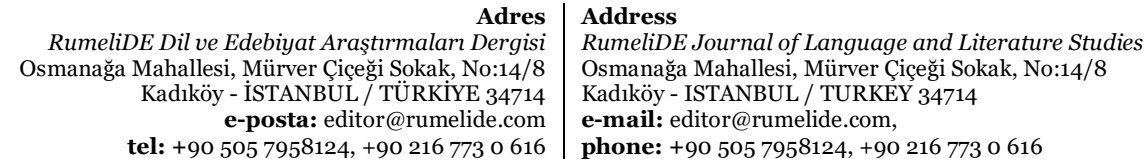


Balçıkanlı, C. (2009). Long Live, YouTube: L2 Stories about YouTube in Language Learning. A. Shafaei \& M. Nejati (Ed.), In Annals of Language and Learning Proceedings of the 2009 International Online Language Conference, (pp. 91-96). USA: Universal.

Bastos, A. \& Ramos, A. (2009). YouTube for learning English as a foreign language: Critical thinking, communicative skills. In EDULEARNo9 Proceedings, (pp. 2087-2092). Barcelona: IATED.

Berk, R. A. (2009). Multimedia teaching with video clips: TV, movies, YouTube and mtvU in the college classroom. International Journal of Technology in Teaching and Learning, 5(1),1-21.

Büyüköztürk, Ş., Çakmak, E. K., Akgün, Ö. E., Karadeniz, Ş. ve Demirel, F. (2016). Bilimsel Araşttrma Yöntemleri (22. Baskı). Ankara: Pegem Akademi.

Catapano, J. (2016). Technology in the classroom: Using YouTube. Web: http://teachhub.blogspot.com/2016/o9/technology-in-classroom-using-youtube.html [Erişim Tarihi: 23.09.2021]

Çangal, Ö. (2020). Yabancllara Türkçe öğretiminde sosyal medya kullanımını yazma becerisine etkisi. [Yayımlanmamış yüksek lisans tezi]. Hacettepe Üniversitesi.

Duisembekova, Z. (2014). The use of English songs on YouTube to teach vocabulary to young learners. [Yayımlanmamış yüksek lisans tezi]. Gazi Üniversitesi.

Fachriyah, E., Badriyah, R. D. M. \& Perwitasari, E. (2020). Using YouTube to evaluate and practice English skills: A case study of blended learning. Advances in Social Science, Education and Humanities Research, 410, 26-29.

Kbooha, R. \& Elyas, T. (2018). The effects of YouTube in multimedia instruction for vocabulary Learning: Perceptions of EFL students and teachers. English Language Teaching, 11(2), 72-81.

Kim, S. \& Kim, H. C. (2021) The Benefits of YouTube in Learning English as a Second Language: A Qualitative Investigation of Korean Freshman Students' Experiences and Perspectives in the U.S. Sustainability, 13(13), 1-16.

Meinawati, E., Rahmah, N. A., Harmoko, D. D. \& Dewi, N. (2020). Increasing English speaking skills through YouTube. POLYGLOT: Jurnal Ilmiah, 16(1), 1-13.

Renaldi, S. (2017). Using Instagram to improve students' ability and interest in writing descriptive paragraphes. [Bachelor's thesis]. Muhammadiyah University of Makassar.

Pujiati, H., Zahra \& Tamela, E. (2019). The use of instagram to increase students' motivation and students' competence in learning English. Advances in Social Science, Education and Humanities Research, 335, 651-656.

Shariff, S. B. M. \& Shah, P. M. (2019). Pupils perception of using YouTube and autonomous learning. Creative Education, 10, 3509-3520.

Voices, B. (2020). Edutainment: Advantages and disadvantages of learning on YouTube. Web: https://swaay.com/edutainment-advantages-and-disadvantages-of-learning-on-youtube [Erişim Tarihi: 18.09.2021]

Yıldırım, A. ve Şimşek, H. (2018). Sosyal Bilimlerde Nitel Araştırma Yöntemleri (11. Baskı). Ankara: Seçkin.

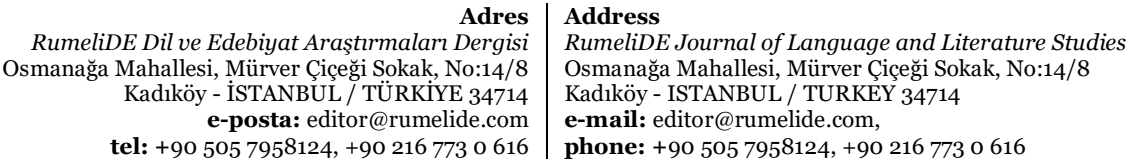

